\title{
Medicinal and Aromatic Plants (MAP) - Adequate Alternative for Rural and Agritourism Development
}

\author{
Assoc. Prof. Edmond Kadiu \\ Dr. Arben Tërpollari \\ Prof. Dr. Stilian Apostoli \\ M. Sc. Erdit Nesturi \\ Assoc. Prof. Majlinda Belegu \\ Assoc. Prof. Ilir Kapaj
}

\section{Doi:10.5901/ajis.2016.v5n3p123}

\begin{abstract}
Land reform of 1991 implemented pursuant to "Law on Land" has generated that is not used during the period from 1991 to 2016 and was named "refused land" for a variety of reasons that are widely recognized by rural world for why and which they are. This land fund by purpose and destination of use is grouped into three categories, where the third, with about 53 thousand hectares, is less fertile, affected by erosion, and should be used with priority. Their expansion results to be $67 \%$ in mountain areas, $31 \%$ in hilly areas and only $2 \%$ in lowland areas. The more effective alternative according to our agriculture theory and practice is that of MAP (medicinal and aromatic plants) that have multi-dimensional cultivating interests for our country, conditioned by the climatic and soil conditions as well as the economic and organizational conditions of a range of stakeholders related to MAP, such as their growers, collectors, aggregators, processors and traders (exporters). In terms of our country MAP have two main situations: a) From the wild, outdoor and, b) Cultivated, in increasingly growing areas, in different areas and with differentiated practices. Among the MAP in complexity, sage, thyme and oregano have obvious superiority in area planted and the production realized out of their total. The advantage of MAP results in full use of agricultural land, in a broader employment of free labor force (mainly women), increase of income, increase of their exports, which currently account for about 52-54 \% of the total that agriculture as a whole realizes in the last years, etc.
\end{abstract}

Keywords: Refused land, fertility of land, barren land, land fragmentation, medicinal and aromatic plants, rural area, agritourism, etc.

\section{Introduction}

With the implementation of the Law on Land No. 7501 of 1991, a fund of 110 thousand hectares of land which was not distributed has remained without destination of use and has been considered as of "refused land" for a variety of wellknown reasons. The purpose and the destination of their use divide those lands into three categories. They have territorial extent (about $70 \%$ in mountain areas) with a distance from the village-commune-city that goes up to $75 \mathrm{~km}$, belong to the 5-10 class of soil fertility (they have low agricultural production potential), in some villages resulting from 300-1000 ha of such lands.

Various alternatives have been currently identified on the possibility of effective use of these lands, but as it turns out so far, the most rational has been the cultivation of different types of MAP in them.

For the last three years (2013-2015) their production has resulted to be respectively in the figures: 7-17.4 and 10.4 thousand tons (6). Production is growing with oscillations over the years, with 2014 as the most successful among the other years. MAP cultivation is of interest in our country. In many respects they demonstrate their advantages as: rational use of land refused, employment growth, increasing incomes, increasing exports, improving the quality of life of rural families, strengthening their pluriactive character, etc.

On the other hand, MAP is one sector or activity that leads gradually to adequate improvement of the reciprocity city - countryside, by employing many free labor forces from the city in the rural areas around it. In this way, in our rural agriculture, some concepts are introduced, addressed by foreign authors, on the urban and rural dialectic improvements, on the perfect villagers and agriculturalists citizens, on the mother land and the young peasants, etc. (7). 


\section{Material and Methods}

Implementation of this material was made possible by observing a series of methodological steps that consisted as follows:

a- Semi-structured interviews with key actors of the value chain of MAP in some areas of the country as: The region of Vlora, Kukes, the Great Highland (Malesia e Madhe) and Shengjergj area in Tirana.

b- Semi-structured interviews with stakeholders in the advisory service and the Ministry of line for the most profitable and most suitable in these areas.

c- Oral evidence and conversations with key people of relevant areas which affect and are affected regarding the cultivation of MAP in variety, quantity and quality increased.

d- The research of a wide literature on MAP in Albania and statistical data on areas under cultivation, the diversity of MAP, the quantities produced and exported, etc..

e- SWOT analysis to identify in our situation and in particular in study areas, as realistically as possible the strengths and opportunities on one hand as well as the weaknesses and threats on the other hand, to boost the development of this sector in rural areas.

f- Economic analysis of the value chain for some of MAP in the studied areas.

g- Designing and conducting surveys with farmers of different areas in the study, ages and genders, cultivating or not MAP and how they judge for their impact on social and economic indicators of rural families (agricultural or not ), in more rational use of agricultural land in general and particularly unappropriated lands, etc.

\section{Results and Discussion}

\subsection{Unappropriated lands and their use}

Changes occurred in the early 90s with the advent of the market economy system enabled the old production structures (agricultural enterprises and agricultural cooperatives) in agriculture to cease, and pursuant to the Law on Land no. 7501 of June 1991 new production structures should be organized, small in size, but numerous (rural agricultural families). This reform on agricultural land not only dismantled and fragmentised the land in our country, but left out of economic circulation a considerable area (110,000 ha), considered refused (not split) because it is not getting owned by the rural agricultural economies due to low fertility, long distances from the centers and settlements, scarce opportunities for the organization of production in them, especially in remote and marginalized mountainous areas, etc. This agricultural land fund can be characterized by analyzing in the perspective as follows:

1- According to the purpose and destination of use (division) grouped in three categories.

The first category (with about 30 thousand ha); They are mostly fertile lands, with about 10 ha plots provided for use in the project "Albania 1 Euro" (Instruction of the Council of Ministers dated 18.07.2012 (1) placing at the disposal of foreign investors.

The second category (with about $27.500 \mathrm{ha}$ ); Land of the former agricultural enterprises are planned for the old former owners of agricultural land (compensation), which so far have received a small amount.

The third category, (with about 53.000 ha); It is refused land, unused, affected by soil erosion and which are lands that should be used with priority.

2- According to the relief where lands are located, it must be said that $67 \%$ of these lands lie in mountainous areas, $31 \%$ in hilly areas and only $2 \%$ in the field. (2)

3- According to the districts where these lands are located, we can emphasize that they have a total involvement of these (in 12 districts), but the share that they have in the total of the refused lands differs. Thus, in the regions of Durres- Shkodra-Kukes-Berat-Vlora this share ranges from 1-3\% of the total; in the regions of Tirana-Fier-Elbasan it ranges from $4.5-8 \%$ of the land; and in other regions from $8.5-10 \%$. Only Korca district occupies $54 \%$ of the total of these lands, where within this total, a share of $76 \%$ is occupied by Korca district. (2)

4- According to the local units they are located on average from 155 ha / municipality (162 municipalities), about 45 hectares for every village (558 villages possess it), 35 ha / land lot (660 land lots). (2)

5- According to the the remoteness of the village - the municipality - the city they result in distances of $1 \mathrm{~km}$ to 75 $\mathrm{km}$, where the minimum distance in 7 districts turns out to be $3 \mathrm{~km}$, while the maximum distance in 8 districts reaches $40-75 \mathrm{~km}$. (2) 
6- By type of lands, based on the class of soil fertility that expresses the production potential (soil fertility), we emphasize that these lands (unappropriated) belong to classes 5-10 of soil fertility. The majority of them belong to the 6th class with $23 \%$ of the total, the 7 th class with $37 \%$ of the total and the 8 th class with $25 \%$ of their total.(2)

7- In 62 villages (or in 12\% of those who possess unappropriated land) a special phenomenon has been evidenced, because in those that are spread over 19 districts, there are over 100 ha of unappropriated land for each of them. On the other hand, 609 ha or $74 \%$ of the unappropriated land of the district are listed in Shengjergj (Tirana); over 300 ha in Kastrat (Dibra), over 1000 ha in five villages of Korca, etc. Only in the districts of Saranda, Delvina and Lezha has not been evidenced this land category that is being analyzed. (2)

From the above, the cultivation of agricultural land especially for the third category, will be conditioned by the area where they are located, the relief of land for each area, the concrete climatic conditions, the type of crops ranging to the area, the needs to work that crops have, market demands for concrete products, the development of land market and agricultural infrastructure, which makes it more attractive to unappropriated land cultivation, etc.

Practically, in our conditions there are many alternatives to rational and efficient use of unappropriated lands, among which we mention medicinal aromatic plants (M.A.P.), which are the object of this paper.

\subsection{MAP - an interest to cultivate them in our country}

The use of unappropriated land through MAP has a number of advantages, among which we mention as the most important the fact that it constitutes an instrument for reducing unemployment in rural areas (especially for women), for increasing income in rural families in general and those with little land in particular; for the protection of lands from erosion, degradation and loss of their agricultural activity, etc.

Cultivation of MAP brings an increase in production almost 6 times higher than those that grow in nature, leads to the development of the processing industry and their fast-growing export. It is estimated that this sector has been employed over 100 thousand people, whose growth depends on the interest of domestic and foreign companies to extend the model of MAP in our country in further width of depth, due to increased market demand for some types of MAP.(3)

The interest to cultivate MAP begins even before the 90 s by the state, for some of them such as rosemary, thymus, Lavanda etc.; meanwhile, it found further expansion over the years of market economy, rationally combining, as appropriate, the way of collecting in the wild (naturally) with the cultivation by rural economies, mainly in flinty lands (gravel), unsuitable for any kind of agricultural crop, etc.

8 kinds of plants have been considered as the most important in the entirety of MAP, but those which occupy the largest cultivation area are:

Table 1. The area and production for three MAP in Albania (3)

\begin{tabular}{|c|c|cc|cc|cc|}
\hline \multirow{2}{*}{ No } & \multirow{2}{*}{ District } & \multicolumn{2}{|c|}{ White Oregano } & \multicolumn{2}{c|}{ Common Sage } & \multicolumn{2}{c|}{ Thyme } \\
& Ha & Tons & Ha & Tons & Ha & Tons \\
\hline $1-$ & Berat & 192 & 48 & 1256 & 522 & 12 & 5 \\
\hline $2-$ & Diber & 10 & 1 & 1037 & 54 & 2113 & 85 \\
\hline $3-$ & Durres & 1807 & 46 & 140 & 21 & 375 & 100 \\
\hline $4-$ & Elbasan & 1708 & 18 & 116 & 43 & 939 & 244 \\
\hline $5-$ & Fier & 20769 & 110 & - & - & 5690 & 32 \\
\hline $6-$ & Gjirokaster & 17139 & 485 & 9232 & 1774 & 10 & 6 \\
\hline $7-$ & Korçe & 16 & 4 & 260 & 97 & 20 & 5 \\
\hline $8-$ & Kukes & 1600 & 86 & 783 & 192 & 1190 & 52 \\
\hline $9-$ & Lezhe & 20 & 2 & 1599 & 451 & 3149 & 327 \\
\hline $10-$ & Tirana & 92 & 8 & 36 & 3 & 5823 & 67 \\
\hline $11-$ & Shkoder & 23 & 3 & 5773 & 1189 & 627 & 33 \\
\hline $12-$ & Vlore & 713 & 241 & 6178 & 1000 & 3341 & 386 \\
\hline $13-$ & TOTALI & 44089 & 1052 & 26377 & 5346 & 23289 & 1341 \\
\hline
\end{tabular}

Based on the above table, we can say that:

a- MAP in general and these crops in particular have a presence throughout the territory (except the common 
sage in Fier).

b- Their concentrations vary according to the regions where they are located. Thus, the most concentrated region results to be that of Fier and Gjirokaster; Common Sage slightly deviates from this concentration and is more concentrated in Gjirokastra, Vlora and Shkodra; whereas thyme is more concentrated in Tirana, Fier, Vlora and Dibra.

c- Opportunities for expansion have been seen in the districts of Tirana (Shengjergj, which has about 610 ha refused, Berat, Dibra, Korca, Gjirokastra, Mallakastra, Elbasan, etc., because a larger number of lands of this category is found there and this will encourage rural development in those areas, by adding income and reducing poverty; they are part-time activities which increase pluriactive character of rural agricultural economies (provide from 17-30 - 60\% of annual household income, subject the area).

The further development and effective MAP gets boost from direct funding support by the government, which has been increased and extended the measures over the years, where in 2015 , for each hectare of cultivated land the amount of 250 thousand ALL has been offered.(4)

MAP concerns that have been numerous and present throughout their geographic distribution are multidimensional and can be reviewed:

a- In environmental terms, it appears with massive erosion (Puka, Dibra, Koman, Çermenikë, Poliçan, Berat, Kukes, Saranda, etc.), caused by deforestation and new lands opening before 1990, by criterionless exploitation of some of MAP where many of them are extinct.

b- In technical and technological terms, it must be said that the level of processing of MAP in the country leaves much to be desired.

c- In social terms it appears with the phenomenon of leaving the population to urban areas, reducing the opportunity to accumulate them, the remoteness of collection points, which prevents interest towards MAP.

d- In institutional terms, they relate to the cooperation Government - MAP industry in Albania for informal performances, sale prices, etc.

e- In terms of bio certification, based on the fact that we have Bio products in MAP, we claim to be among the leaders in the field of MAP trade and marketing, with the label Made in Albania.

On the other hand it turns out the fact that the ratio MAP collection / possible production potential has increased over the years, but meantime it indicates that $30-50 \%$ of production is not converted into monetary value, so necessary for the interests of the country and certain groups of individuals (cultivators - collectors-processors-trader persons). In the structure of income of rural families, those from MAP occupied from 20-23-30\% of their total and opportunities to achieve this share exist.

\subsection{Some economic aspects in the MAP sector}

MAP sector is an important source of income for the country regarding their exportation, that a similar situation has been evidenced for the past years:

Table 2. Disa tregues për eksportet e BAM.(5)

\begin{tabular}{|c|l|c|c|c|c|c|}
\hline No & Name & Measurement Unit & 2011 & 2012 & 2013 & $2013 / 2011$ \\
\hline 1 & Agricultural sector & $000 / \mathrm{ALL}$ & 4.137 .222 & 4.905 .561 & 6.629 .936 & 161 \\
\hline 2 & MAP sector & $000 / \mathrm{ALL}$ & 2.268 .149 & 2.639 .074 & 3.350 .423 & 143 \\
\hline 3 & Ratio 2/1 & $\%$ & 53.7 & 53 & 51.5 & 96.3 \\
\hline 4 & Collection against production potential ration & $\%$ & 51 & 65 & 72 & 141 \\
\hline
\end{tabular}

From the above table it turns out that export in both cases have been increased, on average 14-20\% per annum. MAP share of exports against the agricultural sector results to be over $50 \%$, but the ratio has declined over the years, with about 2 percent per year or about 4 percent in 2013/2011.

By comparing the quantity and value of experts to MAP for the period under review we emphasize that they have almost the same increase rate (6\% more on value aspect), which indicates that there is still much work to be done on the quality of the product and consequently on its sale price.

The indicator is conditional on the number of collectors and the quantity of te wild MAP (70-80 thousand collectors), on the cultivation of MAP from the farmers (an increasingly growing number), on the number and organization of companies for the collection and processing of MAP, as well as the number of people employed varies (from 50-240 
people); on the financial support from various programs, besides the direct state support, etc.

MAP are annual and perennial plants, from which the average annual benefit is conditioned (ranging from 2060 EUR/ha for thyme up to 4610 EUR/ha for for linden plus thyme); settlement of investment (ranging from 1-2 years) as well as the profit for $1 \mathrm{~kg}$ in the case of wild collection of MAP from their natural habitats, a situation that is presented as follows:

Table 3. Analysis of the value chain for some of MAP (Vlora region)

\begin{tabular}{|c|l|c|c|c|c|c|c|}
\hline No & Name & Common Sage & Oregano & Thyme & Black hollyhock (leaf) & White hollyhock (leaf) & Hawthorn flower with leaf \\
\hline 1. & Sale price by the farmer (ALL/kg) & 140 & 180 & 70 & 120 & 140 & 160 \\
\hline 2. & Final sale price (ALL/kg) & 266 & 336 & 168 & 192 & 215 & 241.4 \\
\hline 3. & Profit (ALL/kg) & 63.85 & 18.35 & 39.35 & 9.85 & 12.85 & 11.25 \\
\hline
\end{tabular}

The above table indicates that the profit varies between MAP; the highest price is that of common sage, which justifies the increase of areas planted with this plant.

Only in Malesia e Madhe, there are currently (in 2015) 3140 ha of 700 ha (in 2011) and other 1200 ha are aimed in the coming years. In the MAP structure it occupies $88 \%$ of the area. This varies analysis according to the areas. Thus, for the cost-benefit analysis, the following three are the most likely scenarios in Shengjergj:

a- Two annual plants: fennel and anise.

b- Three 4-5 years plants: commonsage, thyme and oregano.

c- Perennial MAP: linden-laurel, associated with thyme.

Initial costs for annual plants are lower compared with the other two scenarios, where the majority of the initial investment costs consist of buying inputs such as seeds, seedlings, etc.

\section{Conclusions and Recommendations}

From the above analysis, a number of conclusions have been naturally identified as follows:

- With the implementation of the Law on Land No. 7501 of 1991, a fund of 110 thousand hectares of land which remained without destination of use and was considered refused, extending throughout the territory and with production potential of classes $5-10$ of soil fertility.

- The cultivation of MAP is an alternative among many of those that these lands can be put into economic circulation, which provide use of land, increase of employment, increase of income for rural families, strengthening their pluractive character, increased of exports, etc.

- MAP exports have marked a satisfactory increase and occupy 51-54\% of the total achieved from agriculture, with the possibility of improvement in the future.

- Almost 90\% of MAP types are found in the wild, whereas regarding the cultivated MAP, based on cost-benefit analysis, at least three scenarios can be used, which are conditioned from their cultivation areas.

- An over exploitation and use of improper collection techniques has been evidenced, which leads to the fact that many types of MAP (10 of them) are on the list of endangered plants etc.

Considering the above, we could also identify some suggestions that consist in the fact that:

- Export of MAP capable to process would affect revenue growth and further employment of labor force.

- It would be of interest for endangered plants threatened to be extinct if their collection should be stopped and the appropriate set of measures should be taken regarding this.

- More investment from domestic operators to increase processing technology of MAP in the country.

- Farmer's cooperation in the field of production-marketing of MAP would lead to the reduction of their cost, the increase of the negotiating power with various companies and the increase of revenue.

- MAP initially can play a special role in the growth of rural-urban reciprocity employing many free labor force from the city, where appropriate. In this way can be improved the concept addressed by some foreign authors on the urban-rural dialectical improvements, on the real and not the fake love for the village, on the perfect villagers and the urban agriculturalist (farmers), on the land mother and the young peasants, etc. 


\section{References}

Instruction of the Council of Ministers dated 18.07.2012 "On the efficient use of unappropriated lands".

List of unappropriated lands (evidence from Ministry of Agriculture, Rural Development and Water Management), 2013.

Institute for Biological Research, Academy of Sciences, 2015.

The joint Instruction of 2015 between Minister of Agriculture, Rural Development and Water Management and Minister of Finance "On the procedures and the management of the fund of the Programme for Agriculture and Rural Development. MARDWM Statistical annual (INSTAT) - 2011-2013.

Day: June 25, 2016.

Norma Guerri-Quando ero Contadina.

Data from "SALVIA NORD" Group on MAP seedling production in Malesia e Madhe. Year 2014-2015. 